\title{
ANALISIS FRAMING PEMBERITAAN REPUBLIKA ONLINE PADA PERISITIWA TEROR THAMRIN JAKARTA DALAM KERANGKA DAKWAH
}

\author{
Achmad Al Farisi \\ STID Al-Hadid, Surabaya \\ alphrizi@gamil.com
}

\begin{abstract}
Abstrak: Tulisan ini diambil dari salah satu pembahasan tesis yang berjudul "Analisis Framing Peristiwa Teror di Jalan MH.Thamrin pada Media Online", pada tulisan ini spesifiknya membahas framing media Republika Online atas peristiwa terror Thamrin dalam bingkai pesan dakwah. Dilatarbelakangi atas dua hal: pertama, yaitu peristiwa terror Thamrin 14 Januari 2016 yang menjadi pembahasan hangat di banyak media. Kedua, yaitu media Republika Online sebagai media bercitra Islam yang masih eksis di tengah sengitnya persaingan media Online lainnya. Fokus tulisan ini adalah bagaimana media Republika Online menyeleksi fakta dan memaknai peristiwa terror Thamrin. Analisis dilakukan secara kualitatif menggunakan teori framming Robert Entman dengan empat variable, yaitu: define problems (definisi masalah), diagnose causes (diagnosis sebab-akibat), make moral judgements (keputusan moral), dan rekomendasi (treatment recommendations). Hasilnya menunjukkan bahwa Republika Online memaknai peristiwa tersebut sebagai peristiwa kejahatan kemanusiaan yang dilakukan oleh organisasi radikal yang tidak sesuai dengan ajaran Islam, pemaknaan Republika Online sejalan dengan prinsip pesan dakwah yaitu mengangkat/menyelesaikan permasalahan manusia, menjunjung tinggi manusia yang memiliki hak hidup dan menjalani kehidupan beragama dan kehidupan sehari-hari.

Kata Kunci: Teror Thamrin, Republika Online, Framming.
\end{abstract}

\begin{abstract}
This paper is taken from one of thesis analysis entitled "Analisa Framing Peristiwa Teror di Jalan MH. Thamrin pada Media Online / Framing Analysis of Terror Tragedy on MH. Thamrin Street in Online Media." In this paper, it specifically studies about media framing of Republika Online over the Thamrin's terror tragedy under the frame of da'wah message. It is grounded on 2 matters: first, Thamrin's terror tragedy, happened on January, 14th 2016, becomes a current news coverage in many news media. Second, from Republika Online as a news media having an Islamic image, which remains existent in the middle of fierce competition of other Online media. The paper focuses on how Republika Online selects facts and means Thamrin's terror tragedy. The analysis is conducted qualitatively by applying Robert Entman's theory of framing with four variables, namely: defining problems; diagnosing causes, making moral judgments, and making treatment recommendations. The result indicates that Republika Online gives a meaning over the tragedy as a humanity crime which is conducted by a radical organization which is inappropriate to the teachings of Islam. The meaning is in line with the principle of da'wah message, namely: overcoming/solving human problems, upholding the human's right of life and conducting religious life dan daily life.
\end{abstract}

Keywords: Thamrin's terror, Republika Online, Framming. 


\section{Pendahuluan}

Tiap peristiwa yang terjadi di sekitar kita memiliki nilai berita, apalagi peristiwa tersebut peristiwa terorisme, ia akan menjadi bahan pemberitaan utama (headline) dan masif oleh berbagai media massa. Misalnya di koran harian Kompas, terorisme menjadi headline berturut-turut pada bulan Juli-Agustus 2009 dan Maret 2010. Pemberitaan tentang peristiwa terorisme melalui pengeboman Hotel Ritz Carlton dan J.W. Marriot, terbunuhnya Noordin M. Top dan kematian Dulmatin membuat berita terorisme menjadi berita yang selalu menyedot paling banyak oleh khalayak. Majalah Gatra pun juga turut memberitakan tentang peristiwa pengeboman yang terjadi pada tahun 2004 yaitu Bom Bali 1 dan 2. Pemberitaan Peristiwa ini juga dilakukan oleh media Online, seperti www.detik.com, www.republika.co.id, www.Jawapos.com dan www.kompas.com juga memberitakan tentang peristiwa terorisme yang sama, meskipun secara penyajian menggunakan cara yang berbeda. Perisitiwa teror tersebut terjadi diberbagai tempat dengan berbagai sasaran, korban dan pelaku yang beragam. Seperti peledakan bom di Bali, 1 Oktober 2005. Sekurang-kurangnya 22 orang tewas dan 102 lainnya luka-luka akibat ledakan yang terjadi di RAJA's Bar and Restaurant, Kuta Square, daerah Pantai Kuta dan di Nyoman Café, Jimbaran. ${ }^{1}$

Pemberitaan tentang peristiwa terorisme menjadi menarik bagi khalayak, terutama bagi kaum muslim di Indonesia karena

\footnotetext{
1 Prasetyo, "Perubahan Corak Terorisme Di Indonesia Tahun 2000 Hingga Tahun 2013" Jurnal Pertahanan Maret 2014, Volume 4, Nomor 1 (2014): 90.

2 Eriyanto, Analisis Framing Konstruksi, Ideologi dan Politik Media (Yogyakarta: LKIS, 2002), 25-26.
}

selama ini terorisme selalu diidentikkan dengan organisasi Islam radikal. Dari 28 peristiwa terorisme yang terjadi di Indonesia dalam kurun waktu tahun 2000 hingga tahun 2012 terbukti kesemuanya pelakunya adalah bagian dari organisasi yang berafiliasi terhadap agama Islam.

Peristiwa apapun termasuk teroris ketika dimasukkan dalam berita media massa, baik cetak ataupun Online, akan mengalami proses yang disebut dengan social constuctivity atau konstruksi realitas secara sosial. Menurut Eriyanto, berita adalah hasil dari konstruksi sosial, ia selalu melibatkan pandangan, ideologi, dan nilai-nilai dari wartawan atau media. Bagaimana realitas itu dijadikan berita sangat tergantung pada bagaimana fakta itu dipahami dan dimaknai oleh wartawan atau media tersebut. ${ }^{2}$ Dalam pandangan McQuail, ${ }^{3}$ berita sebagai produk institusi sebenarnya memiliki nilainilai/ideologi yang melekat pada institusi media. Hal ini bisa dilihat bagaimana media dan wartawan menginterpretasi realitas terorisme dan bagaimana ia menyajikan realitas tersebut dalam sebuah berita kepada khalayak. Sehingga pada dasarnya berita sebenarnya memiliki unsur obyektifitas yang terbatas.

Untuk bisa mengetahui bagaimana media dan wartawan media tersebut mengkonstruksi peristiwa terorisme melalui berita, maka dapat digunakan pendekatan analisis framing. Analisis ini dipakai untuk membedah cara-cara atau ideologi media saat mengkonstruksi fakta. Analisis ini mencermati strategi seleksi, penonjolan,

3 Denis Mc Quail, Teori Komunikasi Massa Suatu Pengantar, diterjemahkan A. Dharma dan A. Ram (Jakarta: Erlangga 1989), 86. 
dan pertautan fakta ke dalam berita agar lebih bermakna, lebih menarik, lebih berarti atau lebih diingat, untuk menggiring interpretasi khalayak sesuai perspektifnya.

Berbagai analisis framing digagas oleh berbagai ilmuwan, salah satunya adalah Robert N. Entman. Menurut Robert N. Entman, framing bisa dilihat dalam dua dimensi besar, yakni seleksi isu dan penekanan atau penonjolan aspek-aspek tertentu dari realitas/isu. Penonjolan adalah proses membuat informasi menjadi lebih bermakna, lebih menarik, berarti atau lebih diingat oleh khalayak. ${ }^{4}$ Frame tersebut memberikan efek fakta yang akan disampaikan, fakta tersebut dikemas sedemikian rupa dengan berbagai tujuan dan maksud wartawan atau media. Dalam beberapa studi kasus tertentu terdapat frame media yang lebih menonjolkan salah satu calon pasangan saat pemilu kepala daerah, atau lebih menonjolkan salah satu produk tertentu yang dikemas dalam suatu bentuk berita atau laporan fakta.

Akibat dari sebuah representasi fakta peristiwa yang dilakukan oleh wartawan atau media, maka hasilnya, berita tersebut akan memberikan dampak tertentu. Pemberitaan peristiwa teroris yang telah disajikan oleh sebuah media, akan berdampak menghasilkan opini massa, seperti khalayak bersepakat untuk mengutuk pelaku pengeboman yang telah menewaskan orang-orang yang tidak bersalah. Opini berkembang ini muncul sebagai akibat pemberitaan atas korbankorban yang tewas akibat peristiwa terorisme tersebut yang dikonstruksi

\footnotetext{
${ }^{4}$ Eriyanto, Analisis Framing., 53.

5 Robert Entman, "Framing U.S. Coverage of International News: Contrast in Narratives of the KAL
}

sebagai orang yang tidak berdosa tapi menanggung akibat perbuatan yang tidak berperikemanusiaan. Munculnya kecaman terhadap kejadian dan pelaku terorisme oleh masyarakat menjadi salah satu bukti efek dari frame dari sebuah pemberitaan tentang terorisme.

Robert N. Entman mendefinisikan dua bentuk frame, frame pertama adalah, "As mentally stored principles for information processing and as characteristics of the news text" ${ }^{5}$ yang artinya dalam sebuah frame pertama adalah memuat bagaimana prinsip informasi atau berita tersebut disusun, apa motif di balik penyusunan berita tersebut. Sedangkan yang kedua, "Frames also describe attributes of the news itself, and that is the focus of this article. frames reside in the spesific properties of the news narrative that encourage those perceiving and thinking about event to develop particular understandings of the news frames are constructed form and embodied in the keywords, metaphors, concept, symbols, and visual images emphazised in a news narrative" sebuah frame dapat dilihat dari bagaimana wartawan menyusun atribut-atribut di dalam artikel berita. Pembingkaian berita dapat diketahui dari bagaimana konstruksi kata, metafora, konsep, simbol dan tampilan visual dalam sebuah cerita.

Konsep frame Robert Entman yaitu dengan frame dengan mengklasifikasikan pemberitaan sebuah peristiwa menjadi empat poin seleksi isu. Pertama, define problem (pendefinisian masalah), kedua, diagnose causes (memperkirakan masalah

and Iran Air Incidents." Journal of Communication 2006, diakses pada 4 november 22:23, www.researchgate.net/publication/229461133. 
atau sumber masalah), ketiga, make moral judgment (membuat keputusan moral), keempat, treatment recommendation (menekankan penyelesaian). Alasan pemilihan teori milik frame Robert Entman karena teori ini relevan dengan tujuan dari tulisan ini, yaitu mendeskripsikan bagaimana konstruksi sosial peristiwa kejahatan terorisme oleh media Republika Online.

Republika Online adalah salah satu media mainstream di Indonesia yang cukup unik karena menjadi media yang memiliki konten berita Islam yang ditunjukkan dalam salah satu sajiannya pada kategori khazanah atau kanal dunia Islam. ${ }^{6} \mathrm{Hal}$ tersebut dapat diketahui pada menu navigasi yang terletak dibawah web header Republika Online. Dalam kateogori khazanah terdapat menu berita seperti cahaya Islam, hikmah, Islam digest, mualaf, fatwa, ZIS-Wakaf, mozaik, empowering Indonesia, rumah zakat. Sedangkan visi misi yang dimiliki oleh Republika Online mempersiapkan masyarakat Indonesia memasuki masa dinamis. Dengan menggunakan slogan penyemangat "Mencerdaskan Kehidupan Bangsa," Republika berusaha terbuka serta mengupayakan perubahan dan pembaharuan tanpa mengganggu stabilitas yang telah susah payah dibangun. Selin itu Republika Online juga tetap menyajikan menu-menu berita umum seperti news, olah raga, ototek, leisure, inpicture dan lainlain. Yang mencakup beragam minat

6 Republika.co.id, "Kanal dunia Islam," Diakses 13 Januari 2018, :http://www.republika.co.id/kanal/dunia-islam

7 Pupung Arifin, "Persaingan Tujuh Portal Berita Online Indonesia berdasarkan Analisis Uses and Gratifications," Jurnal IImu Komunikasi, Volume 10, Nomor 2, Desember 2013: 195-212 pembaca untuk menemukan berita yang ingin mereka baca.

Republika Online sebagai salah satu media mainstream yang memiliki posisi yang cukup baik dibandingkan dengan media-media mainstream lainnya. Berdasarkan data dari alexa.com (2012) media Republika Online termasuk dari 20 media online atau portal berita dengan pengunjung terbanyak dengan coverage berita di Indonesia. Mediamedia tersebut yaitu, Detik.com (\#8), Kompas.com (\#15), Vivanews.com (\#18), Tribunews.com (\#36), okezone.com (\#38), Tempo.co (\#44), Republika Online (\#66), Antara News (\#106), Liputan6.com (\#132), Metro TV (\#155), Kontan Online (\#182), Media Indonesia (\#192), Bisnis Indonesia (\#192). ${ }^{7}$ Dari 20 portal berita Online tersebut hanya Okezone.com dan Republika Online yang secara khusus menyediakan menu konten berita yang memiliki muatan Islam, Okezone.com dengan judul rubrik Muslim, ${ }^{8}$ sedangkan Republika Online dengan rubrik Khazanah. ${ }^{9}$

Republika.co.id atau Republika Online (ROL) merupakan versi online dari harian Republika. ROL hadir sejak 17 Agustus 1995, dua tahun setelah harian Republika terbit. ROL merupakan portal berita yang menyajikan informasi secara teks, audio, dan video, yang terbentuk berdasakan teknologi hipermedia dan hiperteks. ${ }^{10}$ Republika sendiri sering dikaitkan sebagai media milik umat Islam, dikarenakan kelahiran media ini diprakarsai oleh salah

\footnotetext{
8 Okezone.com, "Muslim" Diakses 13 Januari 2018, https://muslim.okezone.com/

${ }_{9}$ Republika.co.id, "Kanal dunia Islam," Diakses 13 Januari 2018, :http://www.republika.co.id/kanal/dunia-islam

${ }^{10}$ Republika Online "indeks" Diakses pada 3 juni 2016, http://www.republika.co.id/page/about
} 
organisasi Islam ICMI (Ikatan Cendikiawan Muslim Indonesia). ${ }^{11} \mathrm{Hal}$ ini menjadikan Republika Online salah satu media online yang banyak bermuatan informasi yang bermuatan Islam yang cukup banyak. Seperti adanya rubrik khazanah atau rubrik ramadhan, yang berdasarkan hasil pengamatan tidak banyak terdapat pada media online selainnya dalam kurun waktu bulan Januari 2016 hingga Desember 2016.

Salah satu peristiwa teror yang masih lekat dalam ingatan adalah teror yang terjadi di Jakarta pada 14 Januari 2016, yang dikenal dengan peristiwa Teror Thamrin. Teror ini menjadi isu yang cukup hangat pada saat proses penelitian ini berlangsung. Hal tersebut didasari, sebelum terjadinya teror didahului dengan serangkaian teror yang terjadi di kota Paris, Prancis. Teror di Paris menjadi perhatian dunia, dikarenakan Paris pernah mendapatkan predikat sebagai salah satu kota teraman di dunia. ${ }^{12}$ Teror di Paris terjadi pada 13 November 2015 sehingga hanya berjarak kurang lebih dua bulan, perhatian dunia beralih ke peristiwa Teror Thamrin atau Jakarta Attack. Pada saat proses terjadinya teror muncul gerakan media sosial di twitter dengan menggunakan hastag \#KamiTidakTakut, yang kemudian menjadi salah satu hastag trending topic dunia. Teror Jakarta atau Teror Thamrin terjadi setelah sekian lama peristiwa terorisme terjadi di Indonesia. Peristiwa teror tersebut juga terjadi setelah peristiwa terakhir yang terjadi pada 2009 yang terjadi di Jakarta.

Berkembangnya internet dan media online menjadi hal yang menarik untuk diteliti,

${ }^{11}$ Susilawati, “Konstruksi Pemberitaan Media Tentang Rekomendasi Badan Koordinasi Pengawas Aliran Kepercayaan Masyarakat (Bakor Pakem) Mengenai bagaimanakah media seperti Republika dalam menyajikan pemberitaan terorisme, termasuk Teror Thamrin. Apakah di dalam pemberitaan teror yang merupakan berita umum memiliki frame pemberitaan yang tidak bertentangan dengan tujuan dakwah yaitu amar makruf nahi mungkar yaitu mengajak atau memerintahkan kepada kebenaran dan mencegah kemungkaran atau memiliki muatan dakwah.

Berdasarkan latar belakang masalah di atas menjadi menarik untuk mengetahui bagaimanakah Republika Online yang menjadi media online yang memiliki latar belakang didirikan oleh umat Islam dan menjadi media online yang cukup maju dalam menframe peristiwa teror. Untuk itulah, tulisan ini akan menjawab masalah bagaimana proses media Republika Online dalam melakukan framing terhadap peristiwa Teror Thamrin, dan mengaitkannya dengan kerangka dakwah, khususnya aspek pesan dakwah. Tujuan dari tulisan ini menganalisis pembingkaian berita pada Republika Online mengenai perisiwa Teror Thamrin, sekaligus menganalisis pesan dakwah dari framing/pembingkaian tersebut.

Studi ini menggunakan metode kualitatif dengan pendekatan analisis framing. Analisis framing yang digunakan adalah konsep Robert Entman, dan sengaja dipilih karena dianggap mampu mewakili sasaran studi ini. Teknik pengambilan data menggunakan dokumentasi, yaitu mengumpulkan dokumen-dokumen artikel berita online selama tiga hari, yaitu pada tanggal 14 januari hingga 16 januari 2016.

Penghentian Kegiatan Jemaat Ahmadiyah Indonesia (JAI)" (Skripsi), 50.

${ }^{12}$ Sebuah survei dari Economist Intelligence Unit. 
Menurut Sugiyono, ${ }^{13}$ uji kredibilitas data dalam penelitian kualitatif antara lain dapat dilakukan dengan perpanjangan pengamatan, peningkatan ketekunan dalam penelitian, triangulasi, diskusi dengan teman sejawat, analisis kasus negatif, dan membercheck. Uji kredibilitas data menggunakan peningkatan ketekunan, yaitu dengan mengecek kembali berulangulang hasil temuan maupun hasil analisis.

\section{Framing Robert N. Entman}

Framing adalah pendekatan untuk melihat bagaimana realitas itu dibentuk dan dikonstruksi oleh media. Proses pembentukan dan konstruksi realitas itu, hasil akhirnya adalah adanya bagian tertentu dari realitas yang lebih menonjol dan lebih mudah dikenal. ${ }^{14}$ Media senantiasa melakukan seleksi tersebut dalam setiap pemberitaanya. Bagi isu atau fakta yang tidak ditonjolkan, bahkan tidak diberitakan menjadi terlupakan dan sama sekali tidak diperhatikan oleh pembaca. Entman mendefinisikan dua bentuk frame, frame pertama adalah, "As mentally stored principles for information processing and as characteristics of the news text" yang artinya dalam sebuah frame pertama adalah memuat bagaimana prinsip informasi atau berita tersebut di susun, apa motif di balik penyusunan berita tersebut. Sedangkan yang kedua, "Frames also describe attributes of the news itself, and that is the focus of this article. frames reside in the spesific properties of the news narrative that encourage those perceiving and thinking about event to develop particular understandings of them. news frames are constructed form and embodied in the keywords, metaphors, concept, symbols, and visual images emphazised in a news narrative," sebuah frame dapat dilihat dari bagaimana wartawan menyusun atributatribut didalam artikel berita. Pembingkaian berita dapat diketahui dari bagaimana konstruksi kata, metafora, konsep, simbol dan tampilan visual dalam sebuah cerita. ${ }^{15}$

Konsep framing Robert Entman digunakan dalam membedah realitas yang akan diteliti. Dengan konsep framing Robert Entman lebih memudahkan untuk mengungkapkan realitas terorisme. Adapun keempat konsep ini jika dibuat dalam bentuk tabel adalah sebagai berikut:

Tabel 1 - Pernyataan Framing Robert Entman ${ }^{16}$

\begin{tabular}{r|l}
$\begin{array}{r}\text { Define Problem } \\
\text { (Pendefinisian Masalah) }\end{array}$ & $\begin{array}{l}\text { Bagaimana Suatu peristiwa/isu dilihat? Sebagai apa? } \\
\text { Atau sebagai masalah apa? } \\
\text { Diagnose Causes }\end{array}$ \\
$\begin{aligned} \text { Peristiwa itu dilihat disebabkan oleh apa? Apa yang } \\
\text { dianggap sebagai penyebab dari suatu masalah? Siapa } \\
\text { masalah) }\end{aligned}$ & $\begin{aligned} \text { (aktor) yang dianggap sebagai penyebab masalah? } \\
\text { Make moral judgment } \\
\text { (membuat keputusan moral) }\end{aligned}$ \\
$\begin{array}{l}\text { Nilai moral apa yang disajikan untuk menjelaskan } \\
\text { masalah? Nilai moral apa yang dipakai untuk } \\
\text { melegitimasi atau mendelegitimasi suatu tindakan? }\end{array}$ \\
\hline
\end{tabular}

\footnotetext{
${ }^{13}$ Sugiyono, Metode Penelitian Kuantitatif Kualitatif dan R\&D, (Bandung: Alfabeta. 2012), 270

${ }^{14}$ Eriyanto, Analisis Framing., 66.
}

${ }^{15}$ Entman, Framing U.S. Coverage. 4. 
Treatment recommendation (menekankan penyelesaian)
Penyelesaian apa yang ditawarkan untuk mengatasi masalah/isu? Jalan yang ditawarkan dan harus ditempuh untuk mengatasi masalah?
Terdapat beberapa tahapan dalam proses framing dari Robert Entman. Pada dasarnya merujuk pada pemberian definisi, penjelasan, evaluasi dan rekomendasi dalam suatu wacana untuk menekanan kerangkan berfikir tertentu terhadap peristiwa yang diwacanakan.

Pertama, define problem adalah bagaimana realitas didefinisikan atau bagaimana sebuah isu diungkapkan atau dilihat oleh media. Pada tahapan ini adalah tahapan utama dari sebuah framing yang dilakukan oleh wartawan atau media. Sebuah peristiwa yang sama bisa jadi dimaknai berbeda dan bingkai yang berbeda ini akan menyebabkan realitas yang berbeda. Kedua adalah diagnose causes yaitu bagaimana media atau wartawan mencoba mengungkapkan apa yang menjadi penyebab dari sebuah masalah dalam pemberitaannya. Setelah adanya pembingkaian dari sebuah peristiwa yang didefinisikan sesuai dengan wartawan atau individu maka selanjutnya bagaimana wartawan atau media mengungkapkan siapa yang menjadi penyebab masalah atau isu atau apa penyebab dari suatu masalah yang ditonjolkan dalam pemberitaan. Secara tidak langsung sebuah masalah jika dilihat dari pendefinisian yang berbeda maka bentuk penyebabnya pun akan berbeda.

Ketiga, make moral judgment yaitu bagaimana media atau wartawan mengungkapkan nilai moral dari suatu peristiwa yang diberitakan, nilai moral apa yang disepakati, melegitimasi atau mendelegitimasi suatu tindakan. Elemen ini digunakan untuk membenarkan atau memberi argumentasi pada pendefinisian masalah yang sudah ditetapkan di awal. Bagaimanakah wartawan atau media mencoba menonjolkan suatu realitas dengan memberikan penilaian terhadap penyebab masalah. Keempat, treament recommendation yaitu bagaimana media mengungkapkan tentang cara mengatasi isu, atau solusi dari suatu peristiwa, apakah ada ataukah tidak dari suatu isu tersebut. Dalam tahapan ini Entman menjelaskan bahwasanya dalam prosesnya media dalam mengungkapkan nilai yang disematkan kepada penyebab masalah, biasanya pun juga dimunculkan berupa solusi atau penyelesaian yang coba diungkapkan. Hasil dari framing Robert Entman adalah mengidentifikasi empat hal yang menonjol. Pertama pemaknaan terhadap sebuah peristiwa atau define problem, mengetahui penyebab dari sebuah masalah atau diagnose causes, ketiga adalah memberikan penilaian moral atas sebuah peristiwa atau make moral judgment, dan keempat adalah memberikan rekomendasi penyelesaian atau treatmen recommendation. keempat variabel tersebut dapat mengetahui apakah sebuah berita memberikan pemaknaan terhadap sebuah peristiwa teror, mengetahui penyebab teror, memberikan penilaian moral terhadap pelaku dan memberikan saran berupa solusi. Sebuah media massa dapat memiliki satu fungsi dakwah yang dapat diperankan oleh media massa adalah menjaga agar media massa selalu berpihak kepada kebaikan, kebenaran, dan keadilan universal sesuai 
dengan fitrah dan kehanifaan manusia, dengan selalu taat kepada kode etiknya. ${ }^{17}$

Seperti penjelasan di atas tentang terorisme, bahwasannya terorisme merupakan perbuatan yang tidak sesuai dengan nilai-nilai Islam begitu pula dengan peraturan undang-undang negara. Maka jika dalam sebuah pemberitaan terdapat pesan eksplisit atau implisit mengandung pesan yang megarahkan kepada perbuatan yang mendukung terorisme maka termasuk berita yang tidak memiliki nilai dakwah. Maka sebaliknya jika pemberitaan yang diberitakan tidak mendukung peristiwa terorisme maka termasuk pemberitaan yang mengandung nilai dakwah.

Penonjolan fakta tersebut bisa dalam bentuk mendefinisikan peristiwa terorisme apakah sesuai dengan pendefinisian yang ditetapkan oleh pihak berwenang salah satunya menggunakan ukuran Kepolisian Republik Indonesia yang sudah dijelaskan sebelumnya. Atau bagaimana menonjolkan aspek penyebab terjadinya peristiwa terorisme, menonjolkan fakta berita tentang penetapan moral dari pelaku atau penyebab dari peristiwa terorisme. Sehingga dari penggunaan penjelasan tersebut dapat mengarahkan kepada bagaimana pesan dakwah dapat dilihat dari pemberitaan tentang peristiwa terorisme.

Sebuah berita juga dapat dikategorikan sebagai pesan dakwah, jika dalam kontennya memuat pesan-pesan yang mengarahkan pembacanya agar melakukan kebaikan dan menjauhi keburukan yang sesuai dengan Alquran dan Hadis. Alquran berita sering diistilahkan dengan kata

17 Abdul Wahid, Sunardi, Muhammad Imam Sidik, Kejahatan Terorisme - Perspektif Agama, Ham dan Hukum (Bandung: Refika Aditama, 2004), 98.
Annaba', yakni berita yang penting, terjadinya sudah pasti dan membawa manfaat yang besar. Berbeda dengan kata al-khabar yang berarti berita sepele dan sedikit manfaatnya. ${ }^{18}$ Demikian pula pesan yang ingin disampaikan oleh Republika Online dalam memberitakan peristiwa kejahatan Teror Thamrin di Jakarta.

\section{Frame Republika Online terhadap Peristiwa Teror Thamrin}

Fokus masalah dalam studi ini adalah bagaimana mengungkap frame yang dilakukan oleh media Republika Online dalam memberitakan peristiwa Teror Thamrin. Untuk itu dapat menggunakan klasifikasi bentuk frame, berita yang akan dilakukan analisis adalah berita yang mengandung isi berupa pendefinisian peristiwa, penjelasan, evaluasi dan rekomendasi dalam wacana Teror Thamrin. Bentuk berita yang akan dianalisis adalah berupa pendapat pihak-pihak tertentu yang diwawancarai oleh Republika Online sebagai tanggapan atas peristiwa. Dari hasil wawancara tersebut dapat memberikan gambaran berupa narasi dari pemberitaan berupa pendefinisian, penjelasan, evaluasi dan rekomendasi. Klasifikasi tersebut dirasa dapat mewakili berita yang dibutuhkan untuk dilakukan analisis framing menggunakan framing Robert Entman.

Pada tulisan ini berita direduksi dan dibatasi pada yang diperlukan saja. Reduksi data merupakan suatu proses pemilihan, pemusatan perhatian pada

18 lbid., 328 
penyederhanaan, pengabstrakan dan transformasi data kasar yang muncul dari catatan-catatan tertulis di lapangan. Selama pengumpulan data berlangsung, terjadilah tahapan reduksi selanjutnya (membuat ringkasan, mengodekan, menelusuri tema, membuat gugus-gugus, membuat partisi, membuat memo). ${ }^{19}$ Reduksi dilakukan dengan cara menyortir data berita yang berhubungan dengan pemaknaan atau komentar terhadap peristiwa. Dikarenakan dengan pemilihan narasumber akan membentuk sebuah kontruksi tersendiri terhadap satu peristiwa. Dari proses reduksi tersebut ditemukan judul 35 judul berita sebagai berikut.

Tabel 2 - Berita Republika Online Pendefinisian Teror Thamrin

\begin{tabular}{|c|c|c|c|}
\hline No & Judul Berita & Rubrik & Url \\
\hline 1 & $\begin{array}{l}\text { Teror Bom di Pos Polisi } \\
\text { Sarinah, Ketua DPD Akui } \\
\text { Indonesia Kecolongan }\end{array}$ & Nasional & $\begin{array}{l}\text { http://nasional.republika.co.id/berita/nasional/jabodetabek- } \\
\text { nasional/16/01/14/o0xjqw359-teror-bom-di-pos-polisi-sarinah- } \\
\text { ketua-dpd-akui-indonesia-kecolongan }\end{array}$ \\
\hline 2 & $\begin{array}{l}\text { Irman Gusman Kutuk } \\
\text { Serangan Radikal Sarinah }\end{array}$ & Nasional & $\begin{array}{l}\text { http://nasional.republika.co.id/berita/nasional/umum/16/01/14 } \\
\text { /o0xuxs359-irman-gusman-kutuk-serangan-radikal-sarinah }\end{array}$ \\
\hline 3 & DPR: Intelejen Kebobolan & Nasional & $\frac{\text { http://nasional.republika.co.id/berita/nasional/umum/16/01/14 }}{\text { Lo0xr9b365-dpr-intelijen-kebobolan }}$ \\
\hline 4 & $\begin{array}{l}\text { Sarinah Diteror Bom, DPR } \\
\text { Akan Panggil Kepala BIN }\end{array}$ & Nasional & $\begin{array}{l}\text { http://republika.co.id/berita/nasional/umum/16/01/14/o0xvdm } \\
\text { 282-sarinah-diteror-bom-dpr-akan-panggil-kepala-bin }\end{array}$ \\
\hline 5 & $\begin{array}{l}\text { Fahri Hamzah: Teror Bom } \\
\text { Jakarta Kasar dan Biadab! }\end{array}$ & Nasional & $\begin{array}{l}\text { http://republika.co.id/berita/nasional/umum/16/01/15/o0ydr62 } \\
\text { 80-fahri-hamzah-teror-bom-jakarta-kasar-dan-biadab }\end{array}$ \\
\hline 6 & $\begin{array}{l}\text { Teror Bom Disebut } \\
\text { Pengalihan Isu Freeport, Ini } \\
\text { Jawaban DPR }\end{array}$ & Nasional & $\begin{array}{l}\text { http://republika.co.id/berita/nasional/umum/16/01/15/o0ye45 } \\
\text { 280-teror-bom-disebut-pengalihan-isu-freeport-ini-jawaban-dpr }\end{array}$ \\
\hline 7 & $\begin{array}{l}\text { Fadli Zon Akui BIN } \\
\text { Kecolongan }\end{array}$ & Nasional & $\begin{array}{l}\text { http://nasional.republika.co.id/berita/nasional/hukum/16/01/1 } \\
\text { 5/o0z8nz365-fadli-zon-akui-bin-kecolongan }\end{array}$ \\
\hline 8 & $\begin{array}{l}\text { DPR: Aparat Hukum tak Bisa } \\
\text { Sangkal 'Kecolongan' Aksi } \\
\text { Teror Sarinah }\end{array}$ & Nasional & $\frac{\text { http://nasional.republika.co.id/berita/nasional/hukum/16/01/1 }}{\underline{\text { 6/o114fj330-dpr-aparat-hukum-tak-bisa-sangkal-kecolongan- }}}$ \\
\hline 9 & $\begin{array}{l}\text { DPP Hidayatullah Kecam Aksi } \\
\text { terorisme di Sarinah }\end{array}$ & Nasional & $\begin{array}{l}\text { http://nasional.republika.co.id/berita/nasional/umum/16/01/15 } \\
\text { /o0ypit280-dpp-hidayatullah-kecam-aksi-terorisme-di-sarinah }\end{array}$ \\
\hline 10 & $\begin{array}{l}\text { Ketua MPR Sebut } \\
\text { Pengeboman Sarinah Sangat } \\
\text { Terkutuk }\end{array}$ & Nasional & $\begin{array}{l}\text { http://nasional.republika.co.id/berita/nasional/jabodetabek- } \\
\text { nasional/16/01/14/o0xixf301-ketua-mpr-sebut-pengeboman- } \\
\text { sarinah-sangat-terkutuk }\end{array}$ \\
\hline 11 & $\begin{array}{l}\text { Pemuda Muhammadiyah } \\
\text { Kutuk Tindakan Teror di } \\
\text { Sarinah }\end{array}$ & Nasional & $\begin{array}{l}\text { http://www.republika.co.id/berita/nasional/umum/16/01/14/o } \\
\text { 0xio5301-pemuda-muhammdiyah-kutuk-tindakan-teror-di- } \\
\text { sarinah }\end{array}$ \\
\hline 12 & $\begin{array}{l}\text { PP Muhammadiyah Imbau } \\
\text { Masyarakat tidak Panik }\end{array}$ & Nasional & $\begin{array}{l}\text { http://nasional.republika.co.id/berita/nasional/jabodetabek- } \\
\text { masional/16/01/14/o0xkzq301-pp-muhammadiyah-imbau- } \\
\text { masyarakat-tidak-panik }\end{array}$ \\
\hline 13 & $\begin{array}{l}\text { Muhammadiyah Kutuk Aksi } \\
\text { Pengeboman Sarinah }\end{array}$ & $\begin{array}{l}\text { Khazanah } \\
\text { Dunia } \\
\text { Islam }\end{array}$ & $\frac{\text { http://www.republika.co.id/berita/dunia-islam/islam- }}{\text { nusantara/16/01/14/o0xq6d384-muhammadiyah-kutuk-aksi- }}$ \\
\hline
\end{tabular}

19 Sutopo, Metodologi Penelitian Kualitatif, (Surakarta, Sebelas Maret. University Press. 2008). 


\begin{tabular}{|c|c|c|c|}
\hline No & Judul Berita & Rubrik & Url \\
\hline 14 & $\begin{array}{l}\text { Muhammadiyah: Jangan } \\
\text { Kaitkan Sarinah dengan Islam }\end{array}$ & $\begin{array}{l}\text { Khazanah } \\
\text { Dunia } \\
\text { Islam }\end{array}$ & $\begin{array}{l}\text { http://www.republika.co.id/berita/dunia-islam/islam- } \\
\text { nusantara/16/01/14/o0xr3f282-muhammadiyah-jangan-kaitkan- } \\
\text { bom-sarinah-dengan-islam }\end{array}$ \\
\hline 15 & $\begin{array}{l}\text { Bom Sarinah Jangan Lantas } \\
\text { Alihkan Isu Freeport dan } \\
\text { Kepentingan Nasional }\end{array}$ & Nasional & $\begin{array}{l}\text { http://nasional.republika.co.id/berita/nasional/umum/16/01/15 } \\
\text { Lo0yydt365-bom-sarinah-jangan-lantas-alihkan-isu-freeport- } \\
\text { dan-kepentingan-nasional }\end{array}$ \\
\hline 16 & $\begin{array}{l}\text { MUI: Pelaku Bom Sarinah } \\
\text { Jauh dari Nilai Keagamaan }\end{array}$ & Nasional & $\begin{array}{l}\text { http://www.republika.co.id/berita/nasional/umum/16/01/14/o } \\
\text { 0xqdj359-mui-pelaku-bom-sarinah-jauh-dari-nilai-keagamaan }\end{array}$ \\
\hline 17 & $\begin{array}{l}\text { Tragedi Sarinah, MUI: Agama } \\
\text { Manapun tidak } \\
\text { Mentolerirnya }\end{array}$ & Nasional & $\begin{array}{l}\text { http://nasional.republika.co.id/berita/nasional/umum/16/01/16 } \\
\text { o10dzr366-tragedi-sarinah-mui-agama-manapun-tidak- } \\
\text { mentolerirnya }\end{array}$ \\
\hline 18 & $\begin{array}{l}\text { MUI: Aksi Teror di Sarinah } \\
\text { Melanggar Kemanusiaan }\end{array}$ & Nasional & $\begin{array}{l}\text { http://nasional.republika.co.id/berita/nasional/umum/16/01/15 } \\
\text { /o105jk330-mui-aksi-teror-di-sarinah-melanggar-kemanusiaan }\end{array}$ \\
\hline 19 & $\begin{array}{l}\text { PBNU: Negara Jangan Kalah } \\
\text { oleh terorisme }\end{array}$ & Nasional & $\frac{\text { http://nasional.republika.co.id/berita/nasional/politik/16/01/14 }}{\text { Lo0ycf0219-pbnu-negara-jangan-kalah-oleh-terorisme }}$ \\
\hline 20 & $\begin{array}{l}\text { Tindak tegas pelaku Teror } \\
\text { Bom Sarinah }\end{array}$ & $\begin{array}{l}\text { Khazanah } \\
\text { Dunia } \\
\text { Islam }\end{array}$ & $\begin{array}{l}\text { http://www.republika.co.id/berita/dunia-islam/islam- } \\
\text { nusantara/16/01/15/o0ythz313-tindak-tegas-pelaku-teror-bom- } \\
\text { sarinah }\end{array}$ \\
\hline 21 & $\begin{array}{l}\text { PBNU: Negara tidak Boleh } \\
\text { Kalah oleh Teroris }\end{array}$ & Nasional & $\begin{array}{l}\text { http://nasional.republika.co.id/berita/nasional/umum/16/01/15 } \\
\text { Lo0yw8e365-pbnu-negara-tidak-boleh-kalah-oleh-teroris }\end{array}$ \\
\hline 22 & $\begin{array}{l}\text { PBNU Minta Nahdliyin } \\
\text { Bersatu Padu Lawan Teror }\end{array}$ & Nasional & $\begin{array}{l}\text { http://nasional.republika.co.id/berita/nasional/umum/16/01/15 } \\
\text { /o0yxdu365-pbnu-minta-nahdliyin-bersatu-padu-lawan-teror }\end{array}$ \\
\hline 23 & $\begin{array}{l}\text { Sultan HB X Prihatin } \\
\text { Terjadinya Bom di Jakarta }\end{array}$ & Nasional & $\begin{array}{l}\text { http://www.republika.co.id/berita/nasional/jabodetabek- } \\
\text { nasional/16/01/14/o0xjz8301-sultan-hb-x-prihatin-terjadinya- } \\
\text { bom-di-jakarta }\end{array}$ \\
\hline 24 & $\begin{array}{l}\text { Komnas HAM: Negara tidak } \\
\text { Boleh Kalah Hadapi } \\
\text { Terorisme }\end{array}$ & Nasional & $\begin{array}{l}\text { http://nasional.republika.co.id/berita/nasional/umum/16/01/14 } \\
\text { Loxq66365-komnas-ham-negara-tidak-boleh-kalah-hadapi- } \\
\text { terorisme }\end{array}$ \\
\hline 25 & $\begin{array}{l}\text { Terkait Ledakan Sarinah, } \\
\text { Ahok: Itu Tindakan Pengecut! }\end{array}$ & Nasional & $\begin{array}{l}\text { http://nasional.republika.co.id/berita/nasional/jabodetabek- } \\
\text { nasional/16/01/14/o0xqpk359-terkait-ledakan-sarinah-ahok-itu- } \\
\text { tindakan-pengecut }\end{array}$ \\
\hline 26 & $\begin{array}{l}\text { Ahok: Pelaku Pengeboman } \\
\text { Sarinah Pengecut }\end{array}$ & Nasional & $\begin{array}{l}\text { http://nasional.republika.co.id/berita/nasional/jabodetabek- } \\
\text { nasional/16/01/14/o0y5wf282-ahok-pelaku-pengeboman- } \\
\text { sarinah-pengecut }\end{array}$ \\
\hline 27 & $\begin{array}{l}\text { Luhut: Kelompok Teroris } \\
\text { Sebut Serangan Sebagai } \\
\text { 'Orkestra' }\end{array}$ & Nasional & $\begin{array}{l}\text { http://nasional.republika.co.id/berita/nasional/hukum/16/01/1 } \\
\text { 4/o0y6ag282-luhut-kelompok-teroris-sebut-serangan-sebagai- } \\
\text { orkestra }\end{array}$ \\
\hline 28 & $\begin{array}{l}\text { Aksi Teror, PGI Minta Umat } \\
\text { Beragama tak Terprovokasi }\end{array}$ & Nasional & $\begin{array}{l}\text { http://nasional.republika.co.id/berita/nasional/umum/16/01/15 } \\
\text { Lo0yrj9280-aksi-teror-pgi-minta-umat-beragama-tak- } \\
\text { terprovokasi }\end{array}$ \\
\hline 29 & $\begin{array}{l}\text { Mabes Polri tegaskan Aksi } \\
\text { Teror di Sarinah Bukan } \\
\text { Gerakan Islam }\end{array}$ & Nasional & $\begin{array}{l}\text { http://nasional.republika.co.id/berita/nasional/hukum/16/01/1 } \\
\text { 4/o0xvnd330-mabes-polri-tegaskan-aksi-teror-di-sarinah-bukan- } \\
\text { gerakan-islam }\end{array}$ \\
\hline 30 & $\begin{array}{l}\text { Semoga Islam tak Difitnah } \\
\text { dalam Teror Bom Sarinah }\end{array}$ & $\begin{array}{l}\text { Khazanah } \\
\text { Dunia } \\
\text { Islam }\end{array}$ & $\begin{array}{l}\text { http://www.republika.co.id/berita/nasional/umum/16/01/14/o } \\
\text { 0xm6f282-semoga-islam-tak-difitnah-dalam-teror-bom-sarinah }\end{array}$ \\
\hline 31 & $\begin{array}{l}\text { Ustaz Erick Yusuf: Terorisme } \\
\text { Pelampiasan Kekecewaan }\end{array}$ & $\begin{array}{l}\text { Khazanah } \\
\text { Dunia } \\
\text { Islam }\end{array}$ & $\begin{array}{l}\text { http://www.republika.co.id/berita/dunia-islam/islam- } \\
\text { nusantara/16/01/14/o0xml9282-ustaz-erick-yusuf-terorisme- } \\
\text { pelampiasan-kekecewaan }\end{array}$ \\
\hline 32 & $\begin{array}{l}\text { Erick Yusuf Ajak Masyarakat } \\
\text { Bersatu Melawan Terorisme }\end{array}$ & $\begin{array}{l}\text { Khazanah } \\
\text { Dunia } \\
\text { Islam }\end{array}$ & $\begin{array}{l}\text { http://khazanah.republika.co.id/berita/dunia-islam/islam- } \\
\text { nusantara/16/01/14/o0xoek384-erick-yusuf-ajak-masyarakat- } \\
\underline{\text { bersatu-melawan-terorisme }}\end{array}$ \\
\hline
\end{tabular}




\begin{tabular}{|c|c|c|c|}
\hline No & Judul Berita & Rubrik & UrI \\
\hline 33 & $\begin{array}{l}\text { Teror Bom Sarinah, Ustaz } \\
\text { Erick: Mohon Perlindungan } \\
\text { kepada Allah }\end{array}$ & $\begin{array}{l}\text { Khazanah } \\
\text { Dunia } \\
\text { Islam }\end{array}$ & $\begin{array}{l}\text { http://www.republika.co.id/berita/dunia-islam/islam- } \\
\text { nusantara/16/01/14/o0xqaa282-teror-bom-sarinah-ustaz-erick- } \\
\text { minta-perlindungan-kepada-allah }\end{array}$ \\
\hline 34 & $\begin{array}{l}\text { Jangan Kaitkan Teror Bom } \\
\text { Sarinah dengan Agama }\end{array}$ & $\begin{array}{l}\text { Publika } \\
\text { Suara } \\
\text { Pembaca }\end{array}$ & $\frac{\text { http://nasional.republika.co.id/berita/nasional/umum/16/01/15 }}{\text { Lo0ze0a374-jangan-kaitkan-teror-sarinah-dengan-agama }}$ \\
\hline 35 & Teroris, Bukan Cinta Agama & Nasional & $\begin{array}{l}\text { http://www.republika.co.id/berita/nasional/umum/12/10/02/d } \\
\text { unia-islam/islam-nusantara/16/01/15/o0zf0m301-teroris-bukan- } \\
\text { cinta-agama }\end{array}$ \\
\hline
\end{tabular}

1. Identifikasi masalah

(problem identification).

Republika Online mengidentifikasi masalah Teror Thamrin sebagai masalahan kejahatan kemanusiaan didasari beberapa fakta pemberitaan. Pertama, pemberitaan yang dilakukan oleh Republika Online berkenaan atas beberapa hal yang disampaikan oleh beberapa tokoh lembaga Islam seperti PBNU, Muhammadiyah, Hidayatullah, Lembaga Dakwah Kreatif iHAQi dan MUI. Ataupun lembaga pemerintahan seperti lembaga DPR, Ekskutif ataupun yudikatif melihat peristiwa tersebut dalam kerangka peristiwa yang memiliki sifat kekejian, kengerian ataupun pengecut. Teror Thamrin dianggap menjadi masalah kejahatan kemanusiaan dikarenakan teror tersebut melanggar aturan-aturan kemanusiaan, norma-norma masyarakat maupun agama manapun. Sebuah kejahatan kemanusiaan identik dengan adanya bentuk-bentuk pelanggaran. Kejahatan diartikan sebagai sebuah bentuk pelanggaran-pelanggaran terhadap peraturan dan perundangundangan negara. ${ }^{20}$ Maka definisi sebuah kejahatan kemanusiaan adalah pelanggaran terhadap hak-hak manusia, berupa penyerangan atau pembunuhan terhadap orang banyak yang dilatarbelakangi oleh hal tertentu.

Sejalan dengan hal tersebut, frame yang dilakukan oleh Republika Online dengan melakukan wawancara terhadap beberapa narasumber yang memberikan kesan atau pemaknaan terhadap masalah Teror Thamrin semakin memberikan gambaran jelas bahwa Teror Thamrin merupakan masalah kejahatan kemanusiaan. Seperti halnya yang ditampilkan oleh Republika berupa wawancara disampaikan oleh tokoh Muhammadiyah melalui Ketua Umum PP Muhammadiyah Haedar Nashir dan Ketua Umum PCIM Inggris Raya, Zain Maulana menyampaikan bahwa Teror Thamrin merupakan masalah kejahatan kemanusiaan dan sebuah kemungkaran. Sedangkan Pengurus Besar Nahdlatul Ulama (PBNU) digambarkan oleh Republika Online menyeleksi isu dan menonjolkan fakta bahwa peristiwa Teror Thamrin merupakan masalah radikalisme agama dan prilaku yang keji dan mengerikan. Melalui hasil wawancara dengan Ketua Umum PBNU K.H. Said Aqil Siroj memberikan satu pernyataan, "Pembiaran terhadap kelompok-kelompok yang radikal akan menumbuhsuburkan gerakan terorisme dan radikalisme." MUI

20 Asep Saeful Muhtadi, Pengantar IImu Jurnalistik (Bandung: Simbiosa Rekatama Media, 2016), 110. 
dalam frame republika dalam mendefinisikan masalah Teror Thamrin sebagai tindakan yang bertentangan dengan aturan agama Islam dan agama-agama lainnya, serta melanggar prinsip kemanusiaan. Sedangkan Ustaz Erick Yusuf, dalam bingkai Republika Online memberikan gambaran bahwa terorisme merupakan pelampiasan dari bentuk kekecewaan atau keputusasaan yang dicurahkan dalam bentuk perusakan atau penyerangan. Frame yang ditampilkan dalam berita wawancara tokoh selain tokoh agama, seperti Gubernur Jakarta Ahok, Komnas HAM, Menteri Agama, atau anggota DPR yang ditampilkan memberikan label terhadap Teror Thamrin sebagai peristiwa yang biadab, kasar, pengecut, sesuatu yang dikecam dan dikutuk.

Frame berita hasil wawancara tersebut mengarahkan kepada adanya bentuk pelanggaran terhadap norma dan aturan yang ada, khususnya adalah aturan kemanusian, bentuk teror yang mengakibatkan hilangnya nyawa orang lain, dan menimbulkan suatu perasaan kengerian di masyarakat. Dianggap sebagai suatu bentuk kejahatan kemanusiaan. Sehingga dimunculkkannya label seperti pengecut, biadab kasar, dan lain-lain.

Tabel 3 - Frame Pendefinisian Masalah

\begin{tabular}{|c|c|c|}
\hline Judul Berita & Narasumber & Isi Berita \\
\hline $\begin{array}{l}\text { DPP Hidayatullah Kecam Aksi } \\
\text { terorisme di Sarinah } \\
\text { Nasional }\end{array}$ & $\begin{array}{l}\text { Kepala Biro (Humas) DPP } \\
\text { Hidayatullah Mahladi }\end{array}$ & $\begin{array}{l}\text { Serangan teror dapat mengasilkan } \\
\text { ketakutan-ketakutan dan fitnah di } \\
\text { tengah masyarakat. }\end{array}$ \\
\hline "Pemuda Muhammadiyah & Ketum PP Muhammadiyah & Keduanya menyampaikan bahwa Teror \\
\hline $\begin{array}{l}\text { Kutuk Tindakan Teror di } \\
\text { Sarinah" } \\
\text { "Muhammadiyah Kutuk Aksi } \\
\text { Pengeboman Sarinah" }\end{array}$ & $\begin{array}{l}\text { Haedar Nashir, Ketua PCIM } \\
\text { Jerman Raya, Ridho Al Hamdi }\end{array}$ & $\begin{array}{l}\text { Thamrin merupakan masalah } \\
\text { kejahatan kemanusiaan dan sebuah } \\
\text { kemungkaran. }\end{array}$ \\
\hline $\begin{array}{l}\text { Tragedi Sarinah, MUI: Agama } \\
\text { Manapun tidak Mentolerirnya } \\
\text { MUI: Aksi Teror di Sarinah } \\
\text { Melanggar Kemanusiaan }\end{array}$ & $\begin{array}{l}\text { Zainut Tauhid Saadi, Ketua } \\
\text { Bidang Hukum dan } \\
\text { Perundangan MUI Pusat } \\
\text { Ketua Umum Dewan } \\
\text { Pimpinan Majelis Ulama } \\
\text { Indonesia (MUI) Pusat Ma'ruf } \\
\text { Amin }\end{array}$ & $\begin{array}{l}\text { Teror Thamrin adalah bentuk } \\
\text { kebiadaban yang nyata dan melanggar } \\
\text { nilai-nilai dan prinsip kemanusiaan, di } \\
\text { mana tidak ada ajaran agama } \\
\text { manapun yang mentolerirnya }\end{array}$ \\
\hline $\begin{array}{l}\text { "PBNU: Negara Jangan Kalah } \\
\text { oleh terorisme" } \\
\text { "Said Aqil Ajak Warga } \\
\text { Nahdliyin Terus Lawan } \\
\text { Terorisme" }\end{array}$ & $\begin{array}{l}\text { Ketua Umum Pengurus Besar } \\
\text { Nahdlatul Ulama (PBNU) KH } \\
\text { Said Aqil Siroj }\end{array}$ & $\begin{array}{l}\text { Prilaku atau tindakan radikalisme yang } \\
\text { merongrong kedaulatan dalam } \\
\text { berbangsa dan bernegara harus } \\
\text { dilawan. }\end{array}$ \\
\hline $\begin{array}{l}\text { Teror Bom Sarinah, Ustaz } \\
\text { Erick Yusuf: Semoga Islam tak } \\
\text { Difitnah }\end{array}$ & $\begin{array}{l}\text { Pimpinan Lembaga Dakwah } \\
\text { Kreatif iHAQi Ustaz Erick } \\
\text { Yusuf }\end{array}$ & $\begin{array}{l}\text { la menilai, serangan ini merupakan } \\
\text { bentuk teror yang sesungguhnya } \\
\text { dengan menyerang orang-orang yang } \\
\text { tidak bersalah. }\end{array}$ \\
\hline
\end{tabular}

$\begin{aligned} & \text { 2. Penyebab masalah (causal Dalam pemberitaan Republika Online } \\ & \text { interpretation). }\end{aligned}$
kelompok radikal diposisikan sebagai


penyebab dari masalah kejatahan kemanusiaan. Dalam membingkai siapa yang dianggap sebagai aktor dari suatu peristiwa, penyebab di sini bisa berarti apa (what), tetapi juga bisa juga berarti (who). ${ }^{21}$ Hal ini didasari oleh beberapa hal, pertama dari fakta yang ditampilkan dalam pemberitaan Republika Online memberikan arahan secara tidak langsung penyebab terjadinya kejahatan kemanusiaan tersebut adalah kelompok radikal dan pemikiran yang radikal.

Dari total seluruh pemberitaan Republika Online tentang peristiwa Teror Thamrin, 35 judul berita di posting berhubungan dengan penyebutan tentang pelaku dari peristiwa Teror Thamrin. Dalam judul berita yang ditampilkan 14 judul berita menyertakan kata "ISIS" dalam rangkaian terduga pelaku atau organisasi yang bertanggung jawab. Kemudian dalam judul yang ditampilkan Republika Online juga menampilkan dua nama, yaitu "Afif" dan "Bahrun Naim." Afif disini disebutkan sebagai salah satu orang yang melakukan aksi baku tembak dengan aparat polisi. Sedangkan nama Bahrun Naim diberikan label sebagai "otak intelektual" dari peristiwa teror, pemimpin ISIS Asia Tenggara, pemasok dana dan perekrut anggota ISIS. Sedangkan ISIS sendiri dibingkai sebagai organisasi yang mendalangi peristiwa teror tersebut.

Dalam beberapa judul berita juga ditampilkan bentuk klarifikasi dari Republika Online yang berhubungan dengan causes interpretation yaitu 4 judul berita yaitu "Mabes Polri tegaskan Aksi Teror di Sarinah

${ }^{21}$ Eriyanto, Analisis Framing., 190.

22 Bilal Ramadhan, "Mabes Polri Tegaskan Aksi Teror di Sarinah Bukan Gerakan Islam", diaskes pada 11 mei 2016, pukul 20:32 dalam
Bukan Gerakan Islam," "Semoga Islam tak Difitnah dalam Teror Bom Sarinah," "Jangan Kaitkan Teror Bom Sarinah dengan Agama," dan "Surga Seperti Apa yang Kamu Rindu, Catatan Hati Untuk Para Penebar Teror." Judul pertama berasal dari pernyataan "Gerakan teroris ini bukan gerakan agama ataupun gerakan Islam," kata Anton, Kamis (14/1). ${ }^{22}$ Sedangkan judul yang kedua yang menyatakan bahwa Ustaz Erick Yusuf berharap, serangan bom itu tidak membuat Islam difitnah sebagai pihak yang bertanggung jawab. Dan judul yang ketiga berisi pendapat Ketua Umum Yayasan Perguruan Al-Iman Citayam, Bogor, mengatakan aksi teror di Sarinah jangan dikaitkan dengan agama tertentu, terutama agama Islam. Dan yang terakhir berisi sebuah surat terbuka yang mempertanyakan agama yang dianut oleh para teroris.

Dari penjelasan di atas, memberikan gambaran mengenai bagaimana frame dari Republika Online dalam membingkai cause interpretation dari pendefinisian Teror Thamrin sebagai perilaku kejahatan kemanusian. Adanya bentuk penonjolan ISIS, Bahrun Naim, Afif Sebagai pelaku, namun pada sisi lain juga ditonjolkan mengenai pelaku bukan berasal dari Islam sebanyak 4 judul berita seperti yang sudah dijelaskan. Sehingga penyebab dari masalah kejahatan kemanusian yang dibingkai adalah satu kelompok radikal yang tidak memiliki keterhubungan atau keterkaitan dengan Islam.

http://nasional.republika.co.id/berita/nasional/huku m/16/01/14/o0xvnd330-mabes-polri-tegaskan-aksiteror-di-sarinah-bukan-gerakan-Islam 
3. Penilaian moral (moral evaluation). Penilaian terhadap kelompok radikal tersebut dianggap perbuatan hina dikarenakan melanggar aturan kemanusiaan dan agama. Moral evaluation digunakan untuk memberikan pembenaran atau argumen pada penyebab masalah yang diangkat oleh wartawan atau media. Pertama hal tersebut dapat didasari oleh bentuk komentar dari beberapa tokoh seperti pada pendefinisian masalah Teror Thamrin sebelumnya. Untuk memperkuat hal tersebut terdapat 15 judul berita yang menurut penulis memiliki keterkaitan dengan pembingkaian atau penonjolan fakta dari isu teror tamrin. Moral Evaluation yang dilekatkan pertama kali bagi pelaku teror adalah sebutan "terkutuk" "biadab" "kasar" "pengecut dan "teroris goblok." Ungkapan tersebut terdapat dalam 15 judul maupun artikel berita. Hal tersebut dapat dimaknai sebagai bentuk ungkapan negatif atau umpatan. Makna umpatan sendiri jika merujuk dari kamus besar bahasa Indonesia berasal dari kata umpat yang memiliki makna perkataan yang keji (kotor dan sebagainya) yang diucapkan karena marah (jengkel, kecewa, dan sebagainya), sedangkan umpatan sendiri berarti suatu makian. ${ }^{23}$ umpatan tersebut diarahkan kepada prilaku teror sekaligus pelaku teror.

Sedangkan pembingkaian moral evaluation kedua adalah bentuk pelanggaran aturan kemanusiaan dan tidak sesuai dengan ajaran agama dibingkai oleh Republika Online pada berita dengan judul "MUI: Aksi Teror di Sarinah Melanggar Kemanusiaan." $\mathrm{Hal}$ tersebut diperkuat di dalam berita tersebut terdapat hasil wawancara berupa pernyataan tertulis yang diungkapkan oleh Republika Online pernyataan ketua MUI K.H. Ma'ruf Amin sebagai berikut: "Tindakan itu bertentangan dengan agama Islam dan agama-agama lainnya, serta melanggar prinsip kemanusiaan di mana tidak ada satupun ajaran agama yang menolerirnya."

Hal tersebut memberikan penjelasan mengenai bentuk moral evaluation pelanggaran nilai-nilai kemanusiaan dan pelanggaran terhadap ajaran agama manapun. Penjelasan tersebut di bingkai oleh Republika Online pada 4 judul berita dari 15 berita yang membingkai moral evaluation dari Teror Thamrin.

\footnotetext{
${ }^{23}$ Kamus Besar Bahasa Indonesia (KBBI) Kamus versi online/daring (dalam jaringan) Diakses 23 Juni 2016 pukul 21:22 dalam http://kbbi.web.id/umpat
} 


\begin{tabular}{|c|c|}
\hline Judul berita & Nilai Moral yang disematkan \\
\hline $\begin{array}{l}\text { Irman Gusman Kutuk Serangan Radikat Sarinah } \\
\text { Ketua MPR Sebut Pengeboman Sarinah Sangat } \\
\text { Terkutuk } \\
\text { Pemuda Muhammadiyah Kutuk Tindakan Teror di } \\
\text { Sarinah } \\
\text { Terkait Ledakan Sarinah, Ahok: Itu Tindakan } \\
\text { Pengecut! } \\
\text { Fahri Hamzah: Teror Bom Jakarta Kasar dan Biadab! } \\
\text { DPP Hidayatullah Kecam Aksi terorisme di Sarinah } \\
\text { Pakistan Mengutuk Serangan Teror di Jakarta } \\
\text { Secarik Pesan untuk Teroris Goblok }\end{array}$ & $\begin{array}{l}\text { Moral Evaluation yang dilekatkan teror adalah } \\
\text { sebutan "terkutuk", "biadab", "kasar", } \\
\text { "pengecut", dan "teroris goblok". } \\
\text { Hal tersebut dapat dimaknai sebagai bentuk } \\
\text { ungkapan negatif atau umpatan. Umpatan } \\
\text { sendiri berarti suatu makian diarahkan kepada } \\
\text { prilaku teror sekaligus pelaku teror }\end{array}$ \\
\hline $\begin{array}{l}\text { Tragedi Sarinah, MUI: Agama Manapun tidak } \\
\text { Mentolerirnya } \\
\text { Surga Seperti Apa yang Kamu Rindu, Catatan Hati } \\
\text { Untuk Para Penebar Teror } \\
\text { MUI: Aksi Teror di Sarinah Melanggar Kemanusiaan } \\
\text { Teroris, Bukan Cinta Agama } \\
\text { MUI: Pelaku Bom Sarinah Jauh dari Nilai Keagamaan } \\
\text { Terkait Ledakan Sarinah, Ahok: Itu Tindakan } \\
\text { Pengecut! }\end{array}$ & $\begin{array}{l}\text { Moral evaluation kedua adalah bentuk } \\
\text { pelanggaran aturan kemanusiaan dan tidak } \\
\text { sesuai dengan ajaran agama dibingkai oleh } \\
\text { Republika Online. Dimana prilaku teror disebut } \\
\text { sebagai prilaku yang melanggar nilai-nilai } \\
\text { kemanusiaan dan tidak sesuai dengan ajaran } \\
\text { agama manapun. }\end{array}$ \\
\hline
\end{tabular}

\section{Rekomendasi solusi (treatment} recommendation)

Atas semua prilaku dari Teror Thamrin tersebut Republika Online merekomendasikan beberapa hal untuk dilakukan, pertama peningkatan pengamanan objek-objek vital, kedua melakukan deradikalisasi dan mengharapkan masyarakat tetap tenang dan tidak takut. Hal tersebut didasari atas pemberitaan dari Republika yang mengandung saran atau bentuk langkah atau upaya yang mengarahkan kepada bentuk solusi atas masalah yang sudah dibingkai oleh Republika Online. Sejumlah 26 judul berita yang memiliki penonjolan fakta tentang rekomendasi solusi dari masalah yang sudah dibingkai.
Treatment recommendation pertama, meningkatkan pengamanan baik pengamanan berbagai objek vital atau penanganan dengan bentuk penangkapan pelaku teroris. Hal tersebut di bingkai dalam beberapa judul dan isi berita. Dari total berita yang dipublish oleh Republika Online penulis menemukan berita yang berisi tentang bentuk pengamanan objek vital sebanyak 15 berita. Bentuk pengamanan yang dilakukan seperti pengamanan objek vital seperti istana negara, kompleks DPR RI, perbatasan negara, atau peningkatan keamanan di kota-kota yang rawan terjadinya konflik agama. Bentuk pengamanan yang selainnya adalah dengan melakukan investigasi dan penangkapan terhadap para pelaku Teror Thamrin yang masih tersebar di beberapa kota. 
Kedua, Republika Online melakukan upaya deradikalisasi terhadap pemikiranpemikiran radikal agar tidak terjadi kembali bentuk kejahatan kemanusiaan yang bernama Teror Thamrin. Pada pemberitaan Republika Online tersebut terdapat pembingkaian berita dengan isi adanya upaya deradikasliasi dengan mewaspadai WNI yang baru pulang bergabung dengan ISIS, kemudian seperti apa yang disampaikan oleh PBNU pada berita dengan judul "PBNU: Negara jangan kalah oleh terorisme" yang mana K.H. Said Agil Siraj mengatakan negara harus melakukan deradikalisasi. Kemudian adanya bentuk redikalisasi melalui pendidikan anak sejak dini. Untuk lebih lengkapnya dapat dilihat di tabel 5.
Ketiga, adalah dengan menghimbau masyarakat agar tetap tenang dan tidak takut terhadap upaya kejahatan kemanusiaan yang sudah terjadi. Hal ini dibuktikan dengan adanya bentuk penonjolan fakta dengan berita yang berisi himbauan agar masyarakat tetap tenang, Masyarakat bersatu menghadapi teroris, pemberitaan tentang munculnya tanda tagar \#KamiTidakTakut. Pemilihan fakta yang ditampilkan oleh Republika Online dalam menyajikan treatment recommendation dari peristiwa kejahatan kemanusiaan yang didefinisikan di awal, terdapat tiga rekomendasi yang ditampilkan, pertama meningkatkan keamanan, kedua melakukan deradikalisasi, dan menghimbau masyarakat agar tetap tenang. Untuk lebih jelasnya dapat dilihat pada tabel berikut ini.

Tabel 5 - Frame Treatment Recommendation Republika Online

\begin{tabular}{|c|c|}
\hline Judul Berita & $\begin{array}{l}\text { Frame Treatment } \\
\text { Recommendation }\end{array}$ \\
\hline $\begin{array}{l}\text { 1) Pascabom Sarinah, Pelabuhan Bakauheni Dijaga Ketat } \\
\text { 2) Ada Ledakan dan Baku Tembak di Sarinah, Akses Masuk Kompleks } \\
\text { DPR Diperketat } \\
\text { 3) Pascabom Sarinah, Polri Tetapkan Siaga Satu Untuk Indonesia } \\
\text { 4) Ahok Serahkan Pengamanan Jakarta ke TNI dan Polri } \\
\text { 5) Pemerintah Harus Pastikan Negara Aman dari Teror } \\
\text { 6) Polisi Terus Bergerak Sasar Pelaku Teror } \\
\text { 7) Polres Indramayu Tingkatkan Kordinasi } \\
\text { 8) Jakarta Diguncang Teror, Polda Ambon Berlakukan Siaga Satu } \\
\text { 9) Polda Masih Investigas Jaringan Pelaku Teror di Kawasan Thamrin } \\
\text { 10) Polri Tangkap Penerima Dana dari ISIS untuk Teror di Thamrin }\end{array}$ & $\begin{array}{l}\text { Treatment Recommendation, } \\
\text { pertama meningkatkan } \\
\text { pengamanan baik pengamanan } \\
\text { berbagai objek vital atau } \\
\text { penanganan dengan bentuk } \\
\text { penangkapan pelaku teroris }\end{array}$ \\
\hline $\begin{array}{l}\text { 1) Waspadai Warga Indonesia yang Baru Pulang Bergabung dengan } \\
\text { ISIS } \\
\text { 2) PBNU: Negara Jangan Kalah oleh terorisme } \\
\text { 3) Ini Cara Mengajari Anak Mengenal terorisme } \\
\text { 4) Ini Pernyataan Sekjen PBB Atas Bom Sarinah }\end{array}$ & $\begin{array}{l}\text { Treatment Recommendation } \\
\text { kedua, adalah dengan } \\
\text { melakukan upaya deradikalisasi } \\
\text { terhadap pemikiran-pemikiran } \\
\text { radikal agar tidak terjadi kembali } \\
\text { bentuk kejahatan kemanusiaan }\end{array}$ \\
\hline
\end{tabular}




\begin{tabular}{l|l}
\hline \multicolumn{1}{c|}{ Judul Berita } & \multicolumn{1}{c}{$\begin{array}{c}\text { Frame Treatment } \\
\text { Recommendation }\end{array}$} \\
\hline 1) PP Muhammadiyah Imbau Masyarakat tidak Panik & $\begin{array}{l}\text { Treatment Recommendation } \\
\text { ketiga, adalah dengan } \\
\text { 2) PBNU: Negara Jangan Kalah oleh terorisme } \\
\text { 3) Tagar \#KamiTidakTakut Jadi Trending Topic Dunia }\end{array}$ \\
& $\begin{array}{l}\text { tetap tenang dan tidak takut } \\
\text { terhadap upaya kejahatan } \\
\text { kemanusiaan yang sudah } \\
\end{array}$ \\
\hline
\end{tabular}

Sehingga framing yang dilakukan oleh media Republika Online dalam memilih isu dan menonjolkan fakta dari isu dengan menggunakan konsep framing Robert Entman menghasilkan frame berikut ini. Pertama media Republika Online membingkai isu Teror Thamrin dalam bingkai problem identification sebagai sebuah masalah kejahatan kemanusiaan. Hal tersebut didasari atau penonjolan fakta peristiwa teror sebagai suatu masalah kejahatan yang menyangkut nilai-nilai kemanusiaan. Kemudian bingkai causal interpretation Teror Thamrin oleh Republika Online adalah kelompok radikal yang tidak memiliki hubungan dengan agama tertentu. hal tersebut didasari atas interpretasi pelaku yang ditonjolkan adalah kelompok radikal ISIS dan pelaku perseorangan, namun Republika Online juga memilih menampilkan berita yang menyatakan bahwa pelaku teror jauh dari agama Islam. Moral Evaluation yang diungkapkan oleh Republika Online pertama adalah kelompok radikal tersebut disematkan berupa yang dilekatkan teror adalah sebutan "terkutuk" "biadab" "kasar" "pengecut" dan "teroris goblok." Hal tersebut dapat dimaknai sebagai bentuk ungkapan negatif atau umpatan. Umpatan sendiri berarti suatu makian diarahkan kepada prilaku teror sekaligus pelaku teror. Kedua adalah bentuk pelanggaran aturan kemanusiaan dan tidak sesuai dengan ajaran agama dibingkai oleh Republika Online. Kedua perilaku teror disebut sebagai prilaku yang melanggar nilai-nilai kemanusiaan dan tidak sesuai dengan ajaran agama manapun. Treatment Recommendation terdapat tiga hal yaitu melakukan pengamanan objek vital, melakukan deradikalisasi, dan menghimbau masyarakat agar tetap tenang.

Tabel 6. Frame Teror Thamrin adalah Kejahatan Kemanusiaan

\begin{tabular}{r|l}
\hline $\begin{array}{r}\text { Problem Identification } \\
\text { Causal Intrepretation }\end{array}$ & $\begin{array}{l}\text { Masalah Kejahatan Kemanusiaan } \\
\text { Molompok Radikal yang tidak memiliki kaitan dengan agama Islam. }\end{array}$ \\
& $\begin{array}{l}\text { Kelompok tersebut adalah kelompok yang terkutuk, biadab, } \\
\text { pengecut, keras, dan teroris goblok, dan kelompok tersebut } \\
\text { melakukan pelanggaran nilai-nilai kemanusiaan dan agama. }\end{array}$ \\
Treatment Reccomendation & $\begin{array}{l}\text { Melakukan pengamanan tempat-tempat vital, melakukan } \\
\text { deradikalisasi dan menghimbau masyarakat tenang }\end{array}$ \\
\hline
\end{tabular}




\section{Analisa Framing Republika Online dan Muatan Pesan Dakwah}

Pesan dakwah memiliki pemaknaan yang luas, dalam hal ini agama bukan hanya sekedar ajaran-ajaran agama, seperti tata cara salat, etika mengaji Alquran, atau petunjuk manasik haji, tetapi menyangkut seluruh aspek kehidupan beragama dengan segala kompleksitas yang menyertainya. ${ }^{24}$ Oleh karena itu sebuah berita agama bisa berita yang memuat fenomena-fenomena baik kegiatan muslim secara perseorangan ataupun secara kelompok. Pemaknaan terhadap berita terorisme memberikan Stigma teroris sama dengan Islam. Stigma tersebut sudah melekat pada atribut-atribut yang berhubungan dengan sebuah agama. ${ }^{25}$ Terorisme, sudah menjadi fenomena yang melekat pada agama Islam. Seperti yang sudah kami jelaskan pada bab latar belakang masalah, peristiwa terorisme di Indonesia selalu diidentikkan dengan kelompok yang berafilisasi dengan atribut Islam. Sejak tahun 2000 hingga tahun 2012 terjadi sebanyak 27 kasus terorisme yang diidentikan dengan peristiwa pengeboman dan didalangi oleh kelompok yang beratribut Islam.

Sebuah berita dalam sudut pandang positivistik merupakan sebuah informasi atau pesan. ${ }^{26}$ Sebuah berita dapat menjadi sebuah pesan dakwah jika berisi tentang informasi-informasi yang mengarahkan

\footnotetext{
${ }^{24}$ Muhtadi, Pengantar Ilmu Jurnalistik., 104.

25 Mubarok, "Stigmatisasi Pemberitaan Terorisme di Media Massa," Jurnal IImu Komunikasi Interaksi Vol 1, No.1 (2012): 34.

${ }^{26}$ Eriyanto, Analisis Framing., 24.

27 MUl.or.id, "Fatwa Bunga (interest/fa-idah), Terorisme, dan Penetapan Awal Ramadhan, Syawal, dan Dzulhijjah." MUl.or.id. 2003. mui.or.id/wpcontent/uploads/2014/05/Ijtima-Ulama-
}

kepada tercapainya tujuan dakwah, yaitu membuat perubahan bagi para pembacanya untuk amar makruf nahi mungkar, melaksanakan perintah-Nya dan menjauhi larangan-Nya.

Terorisme sendiri bukanlah ajaran yang berasal dari Islam dan sesuatu hal yang tidak dibenarkan di dalam Islam. Hal itu didasari atas beberapa pendapat ulama, pertama ijma' ulama pada tahun 2003 yang menghasilkan fatwa tentang terorisme yang menyatakan bahwa, hukum melakukan teror adalah haram, baik dilakukan oleh perorangan, kelompok, maupun negara. ${ }^{27}$

Dari penjelasan di atas mengenai hukum dari terorisme adalah suatu hal yang dilarang atau diharamkan. Dan terorisme bertentangan dengan ajaran Islam berdasarkan Fatwa Majelis Ulama Indonesia Nomor 3 Tahun 2004 tentang Terorisme. ${ }^{28}$ Hal tersebut didasarkan kepada surah AlMaidah ayat 33, berikut terjemahannya: "Sesungguhnya balasan bagi orang-orang yang memerangi Allah dan Rasul-Nya dan berusaha melakukan kerusakan di muka bumi, yaitu mereka dibunuh atau disalib atau dipotong tangan dan kaki mereka secara bersilang. Yang demikian itu suatu kehinaan bagi mereka di dunia sedangkan di akhirat mereka mendapat siksa yang pedih. ${ }^{229}$

Frame yang ditunjukkan oleh Republika Online bisa dikatakan sebagai sebuah pesan

Lampiran1.pdf (diaskes pada Jumat 24 Juni, 2016). 726.

28 Republika.co.id., "MUI: Terorisme itu hukumnya haram" Diakses 8 Mei 2018,

http://www.republika.co.id/berita/duniaislam/fatwa/11/05/11/ll18kg-mui-terorisme-ituhukumnya-haram

${ }^{29}$ Depag RI, Alquran dan Terjemahannya. 
dakwah atau berita yang mengandung nilai dakwah. Hal ini didasari pertama dari frame yang ditunjukkan oleh Republika Online sesuai dengan ukuran sebuah pesan dakwah dan berita yang muatan peristiwa yang penting, terjadinya sudah pasti dan membawa manfaat yang besar bagi pembacanya. ${ }^{30}$ Frame pertama dalam melihat peristiwa teror Thamrin dilihat sebagai suatu masalah kejahatan kemanusiaan, dengan menetapkan kelompok radikal yang dianggap tidak ada kaitannya dengan Islam, dan label yang diberikan berbentuk umpatan negatif, pelanggaran nilai agama dan kemanusiaan. Rekomendasi penyelesain yang ditampilkan adalah melakukan deradikalisasi, pengamanan objek vital dan mengharapkan masyarakat tetap tenang. Dari pesan berita tersebut memiliki manfaat yang besar bagi pembacanya karena menegaskan bahwa peristiwa teror bukan

Frame mendefinisikan masalah teror thamrin sebagai sebuah masalah kejahatan kemanusiaan dan kelompok radikal bukan dari Islam memiliki kesesuaian dalam dengan fatwa yang ditetapkan MUI bahwa terorisme adalah haram. Dalam hal ini frame yang ditampilkan Republika Online memberikan bentuk label terhadap peristiwa teror sebagai peristiwa kejahatan kemanusiaan, dan meletakkan kelompok ISIS sebagai sumber masalah tersebut. ditambah moral evaluation yang melekatkan nilai negatif terhadap peristiwa teror. Pemaknaan sebuah teror sebagai masalah kejahatan kemanusiaan hal ini juga sesuai dengan surah Almaidah ayat 32 , yang terjemahannya adalah, "Oleh karena itu

30 Moh. Ali Aziz, Ilmu Dakwah, (Jakarta: Kencana, 2004), 328

31 Depag RI, Alquran dan Terjemahannya.
Kami tetapkan (suatu hukum) bagi Bani Israil, bahwa: barangsiapa yang membunuh seorang manusia, bukan karena orang itu (membunuh) orang lain, atau bukan karena membuat kerusakan dimuka bumi, maka seakan-akan dia telah membunuh manusia seluruhnya. Dan barangsiapa yang memelihara kehidupan seorang manusia, maka seolah-olah dia telah memelihara kehidupan manusia semuanya. Dan sesungguhnya telah datang kepada mereka rasul-rasul Kami dengan (membawa) keterangan-keterangan yang jelas, kemudian banyak diantara mereka sesudah itu sungguh-sungguh melampaui batas dalam berbuat kerusakan dimuka bumi." 31

Dalam Tafsir Al-Misbah, surah Almaidah ayat 32 memiliki makna sebagaimana dijelasakan Thahir Ibn Asyur, bahwa ayat di atas memberi perumpamaan, bukannya menilai pembunuhan terhadap seorang manusia sama dengan pembunuhan terhadap semua manusia, tetapi ia bertujuan untuk mencegah manusia melakukan pembunuhan secara aniaya. ${ }^{32}$ Sebagai penegasan bahwa tafsir ayat tersebut menguatkan bahwa pesan mengutuk peristiwa dan pelaku terorisme adalah sejalan dengan perintah Allah, karena prilaku terorisme termasuk prilaku aniaya dan dilarang di dalam Alquran.

Frame yang ditampilkan oleh Republika Online sebagai sebuah pesan dakwah, didasari atas hasil framing media tersebut memiliki keseuaian dengan Fatwa MUI tentang hukum terorisme dan kesuaian dengan nilai yang terkandung dalam surah AlMaidah ayat 33 yang menjelaskan bahwa

\footnotetext{
32 M. Quraish Shihab, Tafsir Al Mishbah: Pesan, Kesan dan Keserasian Al-Qur'an, (Jakarta: Lentera Hati, 2002), 101-102.
} 
Allah akan memberikan siksa yang pedih di akhirat kelak. Hal ini diperjelas dengan pembahasan isi pesan dakwah yang disampaikan Ali Yafie dalam buku komunikasi dakwah, salah satu materi pesan dakwah tidak selalu berkaitan dengan pesan akidah saja atau pesan yang berhubungan dengan kegiatan ukhrowi. Melainkan salah satunya adalah materi dakwah yang berisi tentang masalah manusia. Dimana pesan dakwah yang berhubungan dengan manusia adalah pesan yang menyampaikan bahwa menempatkan manusia pada posisi yang "mulia" yang harus dilindungi secara penuh. Jika dihubungkan dengan frame yang coba dibangun oleh Republika Online adalah dengan mengatakan peristiwa tersebut adalah peristiwa kejahatan kemanusiaan, sehingga dengan menyampaikan hal tersebut sama halnya menganggap peristiwa tersebut menjunjung rendah harkat dan martabat manusia, dengan melakukan tindakan anarkis dan tindakan yang tidak mementingkan nilai-nilai kemanusiaan. Maka pesan tersebut dapat dikatakan sebagai pesan dakwah.

\section{Kesimpulan}

Pemberitaan peristiwa Teror Thamrin yang mengambil kasus berita di situs Republika.co.id dengan rincian 35 berita dapat disimpulkan bahwa frame yang ditampilkan dengan mengemas masalah peristiwa Teror Thamrin sebagai masalah kejahatan kemanusiaan, mengedepankan sumber masalahnya adalah kelompok radikal yang dibingkai bukan berasal dari Islam atau tidak ada kaitannya dengan Islam dan adanya nilai moral negatif, berisi pula rekomendasi yang menyarankan melakukan deradikalisasi. Frame tersebut memiliki keseuaian dengan nilai dakwah amar makruf nahi mungkar. Sehingga dengan begitu Republika Online telah menyampaikan sebuah pesan dakwah.

Hasil studi ini diharapkan dapat menjadi sumbangsih dalam dunia pewartaan Indonesia agar semakin lebih baik lagi dalam melakukan pemberitaannya. Media diharapkan tidak hanya melakukan pemberitaan dengan pijakan pemberitaan mana yang menjadi berita yang menguntungkan secara ekonomi, harapannya dapat juga memberikan edukasi dengan pemberitaan yang cover both side (Pemberitaan yg mengungkapkan dua sisi), misalnya ada berita criminal, maka cover both side mengungkapkan dari sisi pelaku dan korban, Apabila dalam berita terorisme diharapkan bisa membuka dari berbagai sisi. Dalam konteks dakwah dan penyiaran Islam, hasil studi ini diharapkan dapat memberikan khazanah dan wawasan baru terkait penyajian pesan dakwah melalui pemberitaan sebuah peristiwa aktual di masyarakat.

\section{Bibliografi}

Arifin, Pupung. "Persaingan Tujuh Portal Berita Online Indonesia berdasarkan Analisis Uses and Gratifications." Jurnal Ilmu Komunikasi, Volume 10, Nomor 2, (Desember 2013): 195-212 Aziz, Moh. Ali. Ilmu Dakwah. Jakarta: Kencana, 2004.

Depag RI, Alquran dan Terjemahannya. 
Entman, Robert. "Framing U.S. Coverage of International News: Contrast in Narratives of the KAL and Iran Air Incidents." Journal of Communication 2006, Diakses pada 4 november 22:23, www.researchgate.net/publication/229461133.

Eriyanto. Analisis Framing Konstruksi, Ideologi dan Politik Media. Yogyakarta: LKIS, 2002.

Kamus Besar Bahasa Indonesia (KBBI) Kamus versi Online/daring (dalam jaringan) Diakses 23 Juni 2016 pukul 21:22 dalam http://kbbi.web.id/umpat

Mubarok. "Stigmatisasi Pemberitaan Terorisme di Media Massa." Jurnal Ilmu Komunikasi Interaksi Vol 1, No.1 (2012).

Muhtadi, Asep Saeful. Pengantar Ilmu Jurnalistik. Bandung: Simbiosa Rekatama Media, 2016.

MUl.or.id, "Fatwa Bunga (interest/fa-idah), Terorisme, dan Penetapan Awal Ramadhan, Syawal, dan Dzulhijjah." MUl.or.id. 2003. mui.or.id/wp-content/uploads/2014/05/ljtima-UlamaLampiran1.pdf (diaskes pada Jumat 24 Juni, 2016). 726.

Mc Quail, Denis. Teori Komunikasi Massa Suatu Pengantar. Diterjemahkan A. Dharma dan A. Ram Jakarta: Erlangga 1989.

Okezone.com, “Muslim" Diakses 13 Januari 2018, https://muslim.okezone.com/

Prasetyo. "Perubahan Corak Terorisme Di Indonesia Tahun 2000 Hingga Tahun 2013" Jurnal Pertahanan Maret 2014, Volume 4, Nomor 1 (2014)

Ramadhan, Bilal. "Mabes Polri Tegaskan Aksi Teror di Sarinah Bukan Gerakan Islam", diaskes pada 11 mei 2016, pukul 20:32 dalam http://nasional.republika.co.id/berita/nasional/hukum/16/01/14/o0xvnd330-mabespolri-tegaskan-aksi-teror-di-sarinah-bukan-gerakan-Islam

Republika.co.id, “Kanal dunia Islam," Diakses 13 Januari 2018, http://www.republika.co.id/kanal/dunia-islam

Republika.co.id, "Kanal dunia Islam," Diakses 13 Januari 2018, :http://www.republika.co.id/kanal/dunia-islam

Republika.co.id., "MUI: Terorisme itu hukumnya haram" Diakses 8 Mei 2018, http://www.republika.co.id/berita/dunia-islam/fatwa/11/05/11/Il18kg-mui-terorismeitu-hukumnya-haram

Republika Online "indeks" Diakses pada 3 juni 2016, http://www.republika.co.id/page/about

Shihab, M. Quraish. Tafsir Al Mishbah: Pesan, Kesan dan Keserasian Al-Qur'an. Jakarta: Lentera Hati, 2002.

Sugiyono. Metode Penelitian Kuantitatif Kualitatif dan R\&D. Bandung: Alfabeta. 2012.

Susilawati. "Konstruksi Pemberitaan Media Tentang Rekomendasi Badan Koordinasi Pengawas Aliran Kepercayaan Masyarakat (Bakor Pakem) Mengenai Penghentian Kegiatan Jemaat Ahmadiyah Indonesia (JAI)" (Skripsi).

Sutopo. Metodologi Penelitian Kualitatif. Surakarta, Sebelas Maret. University Press. 2008.

Wahid, Abdul. Sunardi. Sidik, Muhammad Imam. Kejahatan Terorisme - Perspektif Agama, Ham dan Hukum. Bandung: Refika Aditama, 2004. 
Achmad Al Farisi 